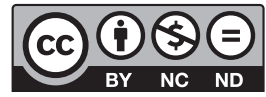

Estudos Teológicos foi licenciado com uma Licença Creative Commons Atribuição - NãoComercial - SemDerivados 3.0 Não Adaptada

http://dx.doi.org/10.22351/et.v60i1.3909

\title{
UM ESTADO "TERRIVELMENTE CRISTÃO" E PRIVATIZADOR: A OPRESSÃO À EDUCAÇÃO EM DIREITOS HUMANOS NO GOVERNO BOLSONARO ${ }^{1}$
}

\author{
A "terribly Christian" and privatizing state: \\ the oppression to education in human rights in the Bolsonaro government
}

\section{Clarissa De Franco ${ }^{2}$ Eduardo Meinberg de Albuquerque Maranhão $F^{03}$}

Resumo: O artigo procura identificar como as perspectivas de privatização e teocratização do atual governo federal, capitaneado por Jair Messias Bolsonaro, tem alicerçado e oprimido a educação - especialmente a educação em direitos humanos. Para observar esse fenômeno, analisamos alguns dos discursos de três representantes ligados à área de educação do governo: Damares Alves, ministra da Mulher, Família e Direitos Humanos, Abraham Weintraub, ministro da Educação, e o recém-nomeado presidente da CAPES, Benedito Guimarães Aguiar Neto. Percebemos nesses discursos a forte presença da ideologia de gênesis, termo nativo que se refere à perspectiva ideológico-religiosa que pressupõe que existem apenas dois sistemas sexo-gêneros (macho-homem / fêmea-mulher) legitimados por Deus e atrelados a uma única orientação sexual desejável, a hétero. Conforme identificamos no estudo, a privatização e teocratização têm sido manejadas de modo a opor-se ao conceito de pluralidade identificado com a coisa pública, havendo por parte de tais mandatários/as a tentativa de garantir que valores de determinados grupos sejam expandidos para a esfera coletiva, sem acompanhar diretrizes e debates internacionais. O texto alicerçou-se em pesquisa bibliográfica-documental com ênfase em notícias vinculadas recentemente pela mídia brasileira, bem como em propostas de políticas públicas voltadas à educação e direitos humanos do governo Bolsonaro, e para a análise das práticas discursivas nos apoiamos na metodologia da Análise Crítica de Discurso de Michel Foucault.

Palavras-chave: Ideologia de gênero e ideologia de gênesis. Educação em Direitos Humanos e religião. Damares Alves, Weintraub e Aguiar Neto. Governo Bolsonaro.

Abstract: The article aims to identify how the prospects for privatization and theocratization of the current federal government led by Jair Messias Bolsonaro have underpinned and oppressed education - especially human rights education. To observe this

1 O artigo foi recebido em 03 de março de 2020 e aprovado em 21 de maio de 2020 com base nas avaliações dos pareceristas ad hoc.

2 Doutora em Ciência da Religião. UFABC. E-mail: clarissadefranco@hotmail.com

3 Doutorado em História Social. Associação Internacional de Estudos de Afetos e Religiões (AMAR). E-mail: edumeinberg@gmail.com 
phenomenon, we analyzed some of the speeches of three representatives linked to the government's education area: Damares Alves, Minister of Women, Family and Human Rights, Abraham Weintraub, Minister of Education, and the newly appointed president of CAPES, Benedito Guimarães Aguiar Neto. We perceive in these speeches the strong presence of the ideology of genesis, a native term that refers to the ideological-religious perspective that assumes that there are only two sex-gender systems (male-man / femalewoman) legitimized by God and linked to a single sexual orientation, desirable, straight. As we identified in the study, privatization and theocratization have been handled in such a way as to oppose the concept of plurality identified with the public thing, with such representatives trying to ensure that the values of certain groups are expanded to the sphere without following international guidelines and debates. The text was based on bibliographic-documentary research with emphasis on news recently linked by the Brazilian media, as well as on public policy proposals aimed at education and human rights under the Bolsonaro government, and for the analysis of discursive practices we rely on the methodology of Analysis Critique of Speech by Michel Foucault.

Keywords: Gender Ideology and Genesis Ideology. Education in Human Rights and Religion. Damares Alves, Weintraub and Aguiar Neto. Bolsonaro Government.

\section{Introdução}

Este artigo propõe analisar algumas das práticas discursivas de três representantes do governo Bolsonaro: Damares Alves, ministra da Mulher, Família e Direitos Humanos, Abraham Weintraub, ministro da Educação, e Benedito Guimarães Aguiar Neto, presidente da Coordenação de Aperfeiçoamento de Pessoal de Nível Superior (CAPES). Nosso olhar se centra na interface entre educação, religião, sexualidade e gênero, tendo como objetivo principal observar as perspectivas de privatização e teocratização que têm alicerçado as políticas educacionais do governo, em confronto com a noção de pluralidade, em especial a pluralidade sexual e de gênero. Tais perspectivas visam garantir a hegemonia de valores de determinados grupos em oposição à diversidade democrática, vista como ameaça. Nesse contexto, a educação em direitos humanos tem sido oprimida por esses valores que se manifestam em falas e propostas políticas do governo Bolsonaro.

Consideramos que existe uma tríade de valores que tem sustentado as ações desse governo: as perspectivas de privatização e teocratização (que serão apresentadas e articuladas ao longo deste texto), e também de militarização (que não contemplaremos aqui, mas em artigos posteriores). Procuraremos demonstrar que tais prepostos do governo realizam uma amálgama entre as concepções de teocratização e privatização em seu sentido amplo, considerando privatização também como uma ação que envolve o campo moral e não somente o financeiro.

Trabalhamos em princípio a importância das práticas discursivas na composição de sociedades democráticas para demonstrar como o campo da educação tem sido vilipendiado pelas perspectivas de privatização e teocratização. Ao final, identificamos tais princípios e outras estratégias discursivas na análise de discurso dos/as três mandatários/as do governo aqui escolhidos/as. 


\section{O campo minado da educação diante das perspectivas de privatização e teocratização}

Optamos por iniciar os debates deste texto refletindo sobre o papel do Estado e como o campo discursivo tem sido fundamental na manutenção do que cada governo entende ser sua função como Estado. Os estados democráticos se caracterizam pela garantia do debate plural, devendo funcionar como mediadores entre indivíduos e coletividade, conforme observa Pablo Santos ${ }^{4}$. Qualquer alteração nesse papel representa um desvio que nos leva à hegemonização e homogeneização de valores e discursos. Eni Orlandi indica que "não há discurso sem sujeito e não há sujeito sem ideologia". Nesse sentido, não cabe pensar em um Estado - que é composto de pessoas - neutro ideologicamente. No entanto, devemos nos ater ao "modo como a ideologia está presente na constituição dos sujeitos e dos sentidos"6. Pensando sobre o manejo da ideologia no governo Bolsonaro, Danielle Rezerai e Raquel D’Alexandre ${ }^{7}$ destacam os mecanismos de hegemonização e homogeneização simbólica e política estabelecidas pela universalização de valores morais. No caso da educação, tal cenário se torna propício para a disseminação ampla e irrestrita de valores que correspondem a grupos específicos e não à pluralidade que caracteriza as sociedades democráticas.

Nesse sentido, conforme observa Guacira Lopes Louro ${ }^{8}$, faz-se necessário observar a educação como um campo de disputa discursiva no qual tais fronteiras têm apontado para abismos cognitivos severos entre as partes, que impedem ou dificultam as políticas. Como observaremos nos discursos aqui analisados, há um reforço às perspectivas de trincheira, disputa ou fronteira ideológica que dificultam políticas públicas igualitárias e equitativas. O pesquisador Homi Bhabha ${ }^{9}$ considera que a construção ideológica da alteridade do "outro" como degenerado ou destituído de legitimidade no discurso dificulta uma política da diferença, operando em uma lógica de poder de apagamento do "diferente". Nesse cenário de fronteiras, acabam ocorrendo alianças e exclusões. Néstor Canclini ${ }^{10}$ sugere que, na América Latina, são estabelecidas alianças entre grupos tradicionalistas, como os fundamentalistas culturais, políticos e religiosos, e grupos renovadores ligados a uma modernização tecnocrática, econômica e de mercado, em função da frágil construção de identidade desse setor. A

4 SANTOS, Pablo Silva Machado Bispo dos. Guia prático da politica educacional no Brasil: Ações, planos, impactos. 2. ed. Cengage Learning, 2012.

5 ORLANDI, Eni. Educação em direitos humanos: um discurso. In: SILVEIRA, Rosa Maria Godoy et al. Educação em Direitos Humanos: Fundamentos teórico-metodológicos. João Pessoa: Editora Universitária, 2007. p. 296.

6 ORLANDI, 2007, p. 296.

7 REZERAI, Danielle do Nascimento; D'ALEXANDRE, Raquel Gomes. Os desafios da educação: Intolerância e inconstitucionalidade do Manifesto à nação (FPE) do programa de governo de Jair Bolsonaro. Revista Interinstitucional Artes de Educar, Rio de Janeiro, v. 5, n. 2, p. 293-312, maio/ago. 2019. p. 295.

8 LOURO, Guacira Lopes. Gênero e sexualidade: pedagogias contemporâneas. Pro-Posições, v. 19, n. 2 (56), maio/ago. 2008.

9 BHABHA, Homi K. O Local da Cultura. Belo Horizonte: UFMG, 1998.

${ }^{10}$ CANCLINI, Néstor Garcia. Culturas Híbridas. São Paulo: EDUSP, 1998. 
educação torna-se um campo em que perspectivas extremistas sobre o tradicional e o moderno são articuladas e disputadas em nome de determinados grupos.

Observa-se que um ponto central no qual operam essas alianças e disputas na educação é a questão de gênero. Garbagnoli e Prearo" ${ }^{11}$ citam a "cruzada antigênero", na qual existe uma clara fronteira entre as pessoas que acusam de "ideologia de gênero" as perspectivas plurais que supostamente pretenderiam aniquilar a família tradicional brasileira, e do outro lado, aquelas que querem garantir a permanência do debate plural sobre gênero e sexualidade e compreendem que a postura de defesa da família tradicional, quando em sua versão extremista, acaba por se tornar um mecanismo de imposição de valores morais à coletividade.

Em artigos anteriores ${ }^{12}$, discutimos o dispositivo da cis-heteronorma ${ }^{13}$, o qual está apoiado na ideologia de gênesis ${ }^{14}$, que propõe a perspectiva bíblica de criação de macho e fêmea a partir de características pré-definidas, sendo o homem imagem e semelhança de Deus e a mulher sua auxiliar e companheira, criada em condição de complemento em relação ao homem (a que veio da costela). A visão de papéis definidos do homem como a estrutura material (do barro) e a mulher como apoio complementar reforça uma série de construções culturais dicotômicas, binárias e preestabelecidas sobre gênero e sexualidade. A cientista das religiões Carolina Teles Lemos ${ }^{15}$ afirma que os papéis de gênero vividos por figuras representativas na narrativa cristã impactam nos lugares reservados às mulheres e aos homens em sociedade.

$\mathrm{O}$ dispositivo cis-heteronormativo com bases religiosas tem se organizado de modo reativo a partir das diretrizes globais de políticas de gênero, que passaram a ser um incômodo para setores religiosos ligados a concepções literais do texto sagrado, desde a década de 1990, quando eclodiu mundialmente a desconstrução da perspectiva de gênero como binária, apontando para a pluralidade e o dinamismo das construções identitárias e das vivências sexuais. ${ }^{16} \mathrm{~A}$ ideia de pluralidade, então, tornou-se opositora dos conceitos tradicionais. E nesse sentido, uma série de antagonismos tem se firmado no debate entre ideologia de gênero e de gênesis, como as instâncias do público e do privado. Pluralidade tornou-se identificada com a coisa pública, com o debate democrático, e, com isso, o campo privativo (como gênero e sexualidade) foi

11 GARBAGNOLI, Sara; PREARO, Massimo. La croisade “anti-genre”. Du Vatican aux manifs pour tous. Paris: Textuel. p. 2017. (Coll. Petiteencyclopédie critique, 128).

12 MARANHÃO Fo, Eduardo Meinberg de Albuquerque; FRANCO, Clarissa De. "Menino veste azul e menina, rosa" na Educação Domiciliar de Damares Alves: As ideologias de gênero e de gênesis da "ministra terrivelmente cristã" dos Direitos Humanos. Revista Brasileira de História das Religiões: ANPUH, ano XII, n. 34, 2019.

13 MARANHÃO Fo, Eduardo Meinberg de Albuquerque. "A travesti morreu, mas carrego ela no caixão" e outras histórias vivas: conversão, transfobia religiosa e morte. Revista Brasileira de História das Religiões, v. 10, n. 9, p. 165-216, 2017.

${ }^{14}$ MARANHÃO, $\mathrm{F}^{\circ}$., Eduardo Meinberg de Albuquerque. "Matando uma leoa por dia": ideologia de gênero e de gênesis na "cura" de travestis. Correlatio, v. 17, n. 2, p. 107-148, 2018.

15 LEMOS, Carolina Teles. Religião e Patriarcado: elementos estruturantes das concepções e das relações de gênero. Caminhos, Goiânia, v. 11, n. 2, p. 201-217, jul./dez. 2013.

16 ROSADO-NUNES, Maria José Fontelas. A “ideologia de gênero" na discussão do PNE: a intervenção da hierarquia católica. Horizonte, Belo Horizonte, v. 13, n. 39, p. 1.237-1.260, 2015. 
cooptado por temas como o das famílias e das religiões (sendo religião vista como algo de foro íntimo, o que não acompanha nossa concepção sobre o fenômeno religioso, presente e pungente no debate público).

Nesse contexto, têm ocorrido alguns movimentos de trazer a educação para o âmbito privado. Eclodiram na última década movimentos como o Escola Sem Partido e Con Mis Hijos No Te Metas, que denotam uma relação de propriedade dos pais e mães com seus filhos e filhas, apartando o Estado da temática de educação sexual e de gênero. O Escola Sem Partido, por exemplo, foi inspirado em movimentos religiosos estadunidenses, como o Save Our Children ${ }^{17}$, e teve como primeiros propositores do projeto de lei nos âmbitos estadual e municipal do Rio de Janeiro os filhos de Bolsonaro, então deputado e vereador: Flávio e Carlos. Jair Bolsonaro, ao longo de seu governo, também sinalizou para a retirada do debate de gênero das escolas. Vimos tal iniciativa se repetir com os governos de Marcelo Crivella ${ }^{18}$, prefeito do Rio de Janeiro, que censurou livros de histórias em quadrinho na Bienal do Livro de 2019 por conta de conteúdo considerado impróprio, e em fevereiro de 2020, quando o governador da Rondônia Marcos Rocha, filiado ao PSL, solicitou a retirada de 43 livros considerados "inadequados às crianças e adolescentes" 19 .

A retirada do debate de gênero das escolas é um exemplo bastante forte da perspectiva de privatização da educação no campo moral, já que o núcleo familiar assume uma importância estratégica para cuidar de debates que na educação em direitos humanos estariam alimentados pela exposição e convivência com a pluralidade. Ao reservar ao núcleo privado da família o espaço para falar (ou não falar) de tais questões, esvaziam-se ou diminuem as possibilidades das crianças e adolescentes consolidarem seus aprendizados práticos relativos ao contato com a diversidade.

É importante pensar que as pessoas que integram a família tradicional (cisgêneras e hétero, especialmente) não sofrem violências físicas como as pessoas homossexuais e transgêneras por suas orientações sexuais e identidades de gênero, e que, até o momento, nenhuma política ou diretriz internacional que promove a pluralidade faz um ataque à existência da família tradicional, e, sim, tenta proteger e garantir direitos das pessoas que não se constituem como tradicionais em suas identidades e vivências. A garantia de direitos das minorias tem sido interpretada equivocadamente por setores superconservadores como um ataque ou uma ameaça à família tradicional, quando essa permanecerá resguardada de seus direitos. O que está em pauta nesse momento é que direitos são esses.

A retirada do debate público de gênero e sexualidade das escolas reedita um velho e central problema de gênero: o de manter no domínio do privado aquilo que se quer controlar, subalternizar, invisibilizar ou excluir, como foi o caso das mulheres por

17 Tal observação pode ser verificada na fala do próprio criador do movimento Escola Sem Partido, o procurador de São Paulo Miguel Nagib, na página: <www.escolasempartido.org> Acesso em: nov. 2018.

18 Marcelo Crivella é bispo da Igreja Universal do Reino de Deus, tendo como curiosidade biográfica o fato de Edir Macedo ser seu tio.

19 Disponível em: <https://brasil.elpais.com/brasil/2020-02-08/censura-de-livros-expoe-laboratorio-doconservadorismo-em-rondonia.html>. Acesso em: fev. 2020. 
muito tempo. ${ }^{20}$ No contexto dos movimentos ligados ao campo educacional, é a criança que tem sido tratada como propriedade privada, alijada de direitos de cidadania públicos em relação à temática de gênero e sexualidade. $\mathrm{O}$ campo discursivo sobre gênero e sexualidade tem afetado de maneira contundente as relações e os processos educacionais.

O núcleo familiar, privativo, torna-se fortalecido no governo Bolsonaro. A pauta da educação domiciliar foi trazida à tona como uma das primeiras iniciativas da ministra Damares Alves. Quando ela propôs a medida provisória para regulamentar a educação domiciliar no Brasil, foi indagada sobre os motivos de tal proposta ter partido do Ministério da Mulher, Família e Direitos Humanos e não do Ministério da Educação. Sua resposta aponta fortemente para dois pilares que estamos observando nas políticas educacionais deste governo: a privatização e a teocratização:

nós entendemos que é direito dos pais decidir sobre a educação dos seus filhos, é uma questão de direitos humanos. Então, a iniciativa sai deste ministério sob esta vertente. [...] E nós somos signatários do Pacto de San Jose da Costa Rica que garante isso às famílias. E veja só, é uma demanda de família isso e tem que sair do ministério da Família. Claro, em parceria e anuência com o ministério da Educação, mas a iniciativa deste ministério é legítima ${ }^{21}$.

Damares Alves evoca em sua fala o Pacto de San José da Costa Rica, também conhecido como Convenção Americana de Direitos Humanos, em vigor desde 18 de julho de 1978. Tal texto da Convenção também é evocado por pessoas adeptas do movimento Escola Sem Partido ${ }^{22}$. Basicamente, o que está em pauta quando esses movimentos trazem à tona a Convenção é a perspectiva de direitos da família. Vejamos os seguintes artigos:

Artigo 12. Liberdade de consciência e de religião

4. Os pais, e quando for o caso os tutores, têm direito a que seus filhos ou pupilos recebam a educação religiosa e moral que esteja acorde com suas próprias convicções.

Artigo 17. Proteção da família

1. A família é o elemento natural e fundamental da sociedade e deve ser protegida pela sociedade e pelo Estado.

2. É reconhecido o direito do homem e da mulher de contraírem casamento e de fundarem uma família, se tiverem a idade e as condições para isso exigidas pelas leis internas, na medida em que não afetem estas o princípio da não-discriminação [sic] estabelecido nesta Convenção.

Há nesse texto toda uma justificativa de que a família deve ser protegida pelo Estado, sendo formada por homem e mulher e que aos pais e mães é reservado o direito de

${ }^{20}$ MAFFÍA, Diana. Contra las dicotomías: feminismo y epistemología crítica. Instituto Interdisciplinario de Estudios de Género, Universidad de Buenos Aires, 2008.

${ }^{21}$ Fala da ministra Damares Alves. Disponível em: <https://g1.globo.com/politica/blog/andreia-sadi/ post/2019/01/25/damares-educacao-domiciliar-permite-a-pais-ensinar-mais-conteudo-e-gerenciaraprendizado.ghtml $>$. Acesso em: fev. 2020.

22 Disponível em: <www.escolasempartido.org $>$ e $<$ www.programaescolasempartido.org $>$. Acesso em: nov. 2018. 
que seus filhos e filhas recebam educação religiosa e moral de acordo com seus valores. Vemos aí os pilares da defesa dos grupos antipluralidade de gênero. Família tradicional, homem e mulher, educação religiosa e moral em casa ou de acordo com a família.

O que devemos notar é que tal documento foi debatido, redigido e aprovado na década de 1970! Após isso, muitos debates e transformações sociais já ocorreram. No campo da educação no Brasil, a Lei de Diretrizes e Bases foi reformulada na década de 1990, novos debates ocorreram nas décadas posteriores, que culminaram no Plano Nacional de Educação (PNE) e na Base Nacional Comum Curricular (BNCC). No campo de gênero, os debates e as pautas se transformaram substancialmente a partir das demandas da terceira onda do feminismo, desde a década de 1990. E no campo religioso, tivemos um maior trânsito religioso desde a década de 1980, a participação de lideranças religiosas cristãs na política com maior intensidade desde os anos 2000, conforme observa Mariano (2011), o debate sobre diálogo inter-religioso articulado frente às demandas recentes de direitos humanos, o fim da política de Estado que proibia os terreiros de religiões afro-brasileiras já há algumas dezenas de anos... Ou seja, diante de tantas transformações envolvendo os três campos: religião, gênero e educação, o ato de nos vincularmos a uma normativa como a Convenção Americana de Direitos Humanos que data da década de 1970 é nos esquivar socialmente de acompanhar todo esse cenário de mudanças históricas, políticas e sociais.

Maria Victoria Benevides ${ }^{23}$, que atua no contexto da educação em direitos humanos, indica que vários setores da sociedade podem e devem promover a formação cidadã em direitos humanos, tanto os formais (como o sistema escolar), quanto diversas organizações e instituições, movimentos sociais, com o objetivo unificado de conscientização sobre as diferenças e a diminuição das desigualdades. No entanto, pelo fato do convívio nas escolas (e a autora se refere mais fortemente às escolas públicas) ser obrigatório, ela entende esse espaço como um "lócus privilegiado", no qual "o diferente tende a ser mais visível e a vivência da igualdade, da tolerância e da solidariedade impõe-se com mais vigor"24.

Em confronto com esse papel das escolas que forma cidadãos e cidadãs para os direitos humanos, a privatização moral e econômica da educação restringe a participação das crianças e adolescentes na pluralidade, priorizando valores de grupos específicos, como os cristãos tradicionais. Conforme observado em artigo no Jornal Folha de S. Paulo: "trata-se de um movimento de buscar refúgio no mundo privativo, em uma tentativa de garantir a prática e disseminação de valores de determinados grupos, fechando-se, assim, à pluralidade do debate público e democrático"25.

Outras propostas explicitam a perspectiva de privatização da educação. Em 2019, o ministro Abraham Weintraub propôs o programa Future-se, que induz as uni-

${ }^{23}$ BENEVIDES, Maria Victoria. Direitos humanos: desafios para o século XXI. In: SILVEIRA et al., 2007, p. $335-350$,

24 BENEVIDES, 2002, p. 347.

${ }^{25}$ FRANCO, Clarissa De. "A Educação oprimida: perspectivas de privatização e teocratização ameaçam o setor". Folha online. Opinião. Tendências/Debates. 05/02/2020. Disponível em: $<$ https://www1.folha. uol.com.br/opiniao/2020/02/a-educacao-oprimida.shtml>. Acesso em: fev. 2020. 
versidades públicas a se abrirem à iniciativa privada. O Future-se veio como uma proposta de adesão voluntária, mantendo a aparente autonomia das universidades federais e também a aparente normalidade democrática. Na gestão de Weintraub, os cortes de verbas na educação tornaram-se severos. Em abril de 2019, o ministro anunciou o congelamento de 1,7 bilhões dos gastos das universidades, atingindo fortemente despesas como: luz, equipamentos de laboratório, pagamento de terceirizados e terceirizadas, bolsas de pesquisa. No anúncio dos cortes, o ministro indicou que as verbas seriam cortadas em algumas universidades específicas, como UNB, UFBA e UFF, que fariam, segundo ele, "balbúrdia"26. Após esse movimento inicial, algumas bolsas foram restabelecidas, a despeito do discurso já ter provocado seu efeito e de boa parte dos cortes ainda prevalecerem. Em fevereiro de 2020, o Ofício 08/2020/ $\mathrm{GAB} / \mathrm{SPO} / \mathrm{SPO}-\mathrm{MEC}$ apontou a normativa das universidades públicas não fazerem contratações, progressões, horas extras nem nenhum tipo de despesa com pessoal ativo e inativo sem previsão orçamentária, anunciando que a previsão deste ano seria de 2,7 milhões a menos que o ano anterior. Sem verbas, muitas universidades públicas se veem seduzidas pela privatização.

O programa Future-se vincula as universidades públicas aos interesses das instituições que injetam seu dinheiro ali. Tal política abre caminho para que as instituições privadas que financiarem as universidades tenham legitimidade para definir os temas das pesquisas, as contratações de docentes e funcionários e funcionárias, as decisões administrativas... A universidade "pública" estará submetida aos interesses de quem a financia. É um projeto de gradualmente fazer com que o público torne-se privado.

Junto com a privatização, a teocratização pode ser observada em muitas práticas do governo Bolsonaro, desde o slogan de campanha ("Brasil acima de tudo, Deus acima de todos" $)^{27}$, seu discurso de posse no qual Bolsonaro citou a palavra "Deus" seis vezes, além de ter declarado apoio nominal à tradição judaico-cristã ${ }^{28}$, a escolha de ministros e ministras como Damares Alves, pastora, além de outras lideranças (recentemente tivemos a nomeação de Benedito Aguiar Neto, presbiteriano reitor da Universidade Mackenzie, para a presidência da CAPES), além de relações muito próximas com representantes da bancada cristã no Congresso. E também, como já apontado, valores que interferem no campo educacional, como a ideologia de gênesis, indicam um movimento de teocratização do Estado.

${ }^{26}$ Disponível em: <https://g1.globo.com/educacao/noticia/2019/05/15/entenda-o-corte-de-verba-dasuniversidades-federais-e-saiba-como-sao-os-orcamentos-das-10-maiores.ghtml >. Acesso em: jan. 2020.

${ }^{27}$ Sobre teocratização no governo Bolsonaro, recomendamos MARANHÃO F ${ }^{\circ}$, Eduardo Meinberg de Albuquerque; COELHO, Fernanda Marina Feitosa; DIAS, Tainah Biela. "Fake news acima de tudo, fake news acima de todos": Bolsonaro e o "kit gay", "ideologia de gênero" e fim da "família tradicional". Correlatio, v. 17, n. 2, p. 65-90, 2018.

${ }^{28} \mathrm{O}$ discurso de posse pode ser observado na íntegra em: $<$ https://www1.folha.uol.com.br/poder/2019/01/ leia-a-integra-do-discurso-de-bolsonaro-na-cerimonia-de-posse-no-congresso.shtml $>$. Acesso em: fev. 2020. O trecho específico sobre a tradição judaico-cristã é: "Vamos unir o povo, valorizar a família, respeitar as religiões e nossa tradição judaico-cristã, combater a ideologia de gênero, conservando nossos valores. O Brasil voltará a ser um país livre das amarras ideológicas”. 
Como se pode observar, não se trata de um caso isolado no governo Bolsonaro, mas de um conjunto de práticas. São arranjos que têm afastado crianças e adolescentes de uma educação cidadã plena, voltada a uma conscientização de direitos humanos. A pluralidade, nesse sentido, identificada com o debate público, é vista como ameaça. Não se pode falar de direitos humanos sem a exposição de crianças e adolescentes às vivências plurais.

\section{Práticas discursivas de Damares Alves, Abraham Weintraub e Benedito Aguiar Neto que revelam privatização e teocratização}

Apresentamos agora alguns discursos das três figuras que representam o governo Bolsonaro e interferem na temática da educação: os ministros Abraham Weintraub e Damares Alves e o novo presidente da CAPES Benedito Aguiar Neto. Embora nem todas as falas tratem exclusivamente do campo educacional, entendemos que dentro do debate da educação em direitos humanos, temas que tocam as minorias compõem parte fundamental da análise.

Poderemos observar nas práticas discursivas elencadas as perspectivas de privatização e teocratização articuladas, e, com base na Análise Crítica de Discurso, identificar alguns pontos, como a história do discurso, as estratégias discursivas, os desejos e as intenções dos discursos, as alianças e exclusões que se estabelecem nas narrativas, quem são os sujeitos e as sujeitas de fala e para quem a fala é dirigida, quais as expectativas sociais que o discurso cobre. As práticas discursivas revelam valores, indicam métodos, sugerem alianças e desafetos. Assim, por meio da análise discursiva, em especial uma análise crítica de discurso como a escola francesa ligada aos estudos de Michel Foucault ${ }^{29}$, podemos observar de que modo as relações de poder são estabelecidas e reproduzidas por meio dos discursos e as formas de normatização das subjetividades provocadas pelo ato discursivo.

\section{DISCURSO 1:}

"Queremos colocar um contraponto à teoria da evolução e disseminar que a ideia da existência de um design inteligente pode estar presente a partir da educação básica, de uma maneira que podemos, com argumentos científicos, discutir o criacionismo."

Benedito Aguiar Neto, em outubro de $2019^{30}$

O discurso de Benedito Aguiar Neto representa um sujeito de fala: "queremos colocar um contraponto...". Quem "queremos"? Além dele, quem o novo presidente da CAPES está carregando em seu discurso? A fala de Benedito foi proferida no contexto

${ }^{29}$ FOUCAULT, Michel. A arqueologia do saber. 8. ed. Rio de Janeiro: Forense, 2016; FOUCAULT, Michel. A ordem do discurso. São Paulo: Loyola, 1996; FOUCAULT, Michel. Estratégia, poder-saber. Rio de Janeiro: Forense Universitária, 2012. (Coleção Ditos e Escritos, v. 4).

${ }^{30}$ A fala ocorreu em um evento sobre a Teoria do Design Inteligente, na Universidade Presbiteriana Mackenzie. Disponível em: <https:/g1.globo.com/jornal-nacional/noticia/2020/01/28/novo-presidente-dacapes-gera-polemica-ao-defender-criacionismo.ghtml>. Acesso em: 26 jan. 2020. 
de uma palestra do maior expoente da Teoria do Design Inteligente, Michel Behe, ocorrida na Universidade Presbiteriana Mackenzie, em São Paulo, da qual é reitor. Benedito Aguiar Neto falou em nome do grupo de adeptos e adeptas dessa teoria, que é discutida por cientistas, embora exista um consenso internacional de que sua base é religiosa $-\mathrm{e}$ fundamentada no dispositivo da cis-heteronorma que caracteriza a ideologia de gênesis, bastante propagada por setores conservadores da sociedade, incluindo os religiosos.

Nosso foco não é debater os fundamentos do Design Inteligente, tampouco legitimar a Teoria da Evolução ou deslegitimar cientificamente o discurso do Design Inteligente. Sabe-se que o pensamento científico opera com base em hipóteses que estão constantemente expostas à análises, críticas, refutações e reformulações, no entanto - e isso sim nos interessa -, o discurso do Design Inteligente tem sido utilizado por grupos mistos entre religião e ciência, com a finalidade de legitimação do discurso de criação (diretamente relacionado à ideologia de gênesis), que se apoia em narrativas religiosas, em especial bíblicas. Nosso interesse na análise de discurso é compreender que esse sujeito da fala de Benedito é um grupo específico, minoritário, com determinados valores que não atendem à comunidade científica majoritária internacional.

Ao utilizar um lugar de fala de poder institucional (desde os tempos de reitor da Mackenzie, e agora mais fortemente como presidente da CAPES), Benedito atua no perigoso terreno de legitimação da universalização de valores privados em âmbito coletivo. As perspectivas de privatização e teocratização, assim, se fundem de maneira estrutural, dando vitalidade ao discurso do novo presidente da CAPES.

A expectativa social que atende o discurso de Benedito é a de seus e suas colegas presbiterianos, e mais amplamente, de seus e suas aliadas cristãs. $\mathrm{O}$ desejo declarado no discurso de Aguiar Neto é que o Design Inteligente esteja presente desde a educação básica. Há que se pensar que temas como economia e direito - há muito estabelecidos - seguem fora das matrizes curriculares básicas. A Teoria do Design Inteligente, perto dessas áreas há muito estabelecidas, é certamente um discurso minoritário depositário do desejo de um grupo que quer expandir seus valores. Foucault lembra que o discurso "é aquilo pelo que se luta"31, indicando que o desejo está diretamente ligado às estratégias de convencimento.

\section{DISCURSO 2:}

“É o seguinte, ó, pode espernear, os 'ólogos'. Os pais e mães estão concordando comigo. Pergunte para um pai de uma menina de doze anos se ele não quer ouvir exatamente isso que eu estou falando. Olha, 'ólogos', eu passo na rua e estou sendo aplaudida. Eu estou ouvindo o povo. Chega da gente induzir nossas crianças para o sexo cada vez mais cedo. Eu só quero conversar sobre isso.

Se o adolescente disser: 'ó, ouvi a senhora, mas eu optei por começar a fazer sexo com 11 anos', é entre ele e o pai. A gente não vai fazer nenhuma interferência, a gente só quer uma outra

\footnotetext{
${ }^{31}$ FOUCAULT, 1996, p. 10-11.
} 
conversa. 'Ministra, mas isso dá certo?' Dá, nós temos pesquisas dizendo que dá. [...] Nós temos experiência nos Estados Unidos, temos mais sete países falando sobre isso."

Damares Alves, 17/01/2020, no programa "Pra cima deles", da Jovem Pan News ${ }^{32}$

A narrativa de Damares Alves foi mobilizada pela pergunta do apresentador Sílvio Navarro da jovem Pan News sobre a fala da ministra, dias antes do programa, acerca da política de retardar a iniciação sexual, chamada por ela mesma de abstinência sexual. Seu discurso começa com "é o seguinte", uma expressão contundente, utilizada por quem não está se importando em manter a formalidade ou cordialidade do debate. "É o seguinte" equivale a "vou dizer o que penso e pronto". O discurso é dirigido a pessoas interlocutoras bastante específicas, a quem Damares chama de "ólogos", referindo-se - como fica subentendido - a estudiosos e estudiosas de diversas áreas que têm estabelecido interlocução e feito críticas às suas falas e atuações como ministra. A palavra "ólogos" é repetida duas vezes, em um claro reforço narrativo. O reforço, para Foucault ${ }^{33}$, é uma prática discursiva que se materializa em poder.

Além disso, o discurso da Damares tem tom provocativo e chama o público para a percepção de uma disputa entre distintos lados, o dos "ólogos" e o dos pais e mães. Ao estabelecer tais fronteiras, Damares coloca-se ao lado do mundo privado, do núcleo familiar. As principais alianças do discurso de Damares Alves são com a família e com a ideia de "povo", uma concepção genérica que traz a sensação de amplitude de seus domínios e alianças. "Passo na rua e estou sendo aplaudida. Eu estou ouvindo o povo." Há uma oposição discursiva entre o "povo" (leigo), com o qual Damares estabelece aliança, e os "ólogos" (aqueles que estudam e conhecem), que ocupam posição de rivalidade no discurso. Ao desestabilizar o lado que ela afirma como oposto ao povo, a ministra estabelece uma dicotomia entre popular e erudito, privado e público. $\mathrm{Na}$ análise de discurso, fortalecer a instância do público torna-se uma estratégia de conferir legitimidade ao enunciado, na medida em que há um respaldo coletivo para tal discurso. ${ }^{34}$ Essa estratégia, além de reforçar a perspectiva de disputa ideológica e desvitalizar o discurso científico dos "ólogos", associa saber popular com poder.

Importante, na análise discursiva, perceber que o lugar da ciência se modifica ao longo da narrativa. No começo, como já observamos, é um lugar desvitalizado, contudo, no final da fala de Damares, ela se apoia em uma estrutura e argumentação científicas para validar seu ponto de vista, quando afirma que "temos pesquisas dizendo que dá (certo)". No momento em que a narrativa científica passa a ter valor para a fala, a ministra resgata seu lugar e se vale de seu prestígio para legitimar suas políticas. Vale-se, inclusive, do prestígio dos Estados Unidos, um país mundialmente conhecido por seu poder e eficácia em lidar com dados. Nesse sentido, o discurso preserva o lugar respeitado da ciência, no entanto, ataca e desqualifica as pessoas que representam a ciência. Um

32 Disponível em: < https://jovempan.com.br/videos/programas/pra-cima-deles/pracimadeles-entrevistacom-a-ministra-damares-alves-17-01-2020.html>. Acesso em: fev. 2020.

${ }^{33}$ FOUCAULT, 2016.

${ }^{34}$ FOUCAULT, 2016. 
importante paradoxo que passa a ser estratégico, já que negar em absoluto os méritos da ciência seria contraproducente em relação à necessidade de convencimento e estabelecimento de alianças. Atacam-se as pessoas, os "ólogos", e preserva-se o pilar da ciência, que encontra legitimidade e respaldo entre o grande público.

Os desejos revelados na fala de Damares referem-se, principalmente, a ganhar a opinião pública, os pais e mães, e o senso comum como aliados e aliadas. Há, ainda, um desejo claro de desvitalização do prestígio social de estudiosos e estudiosas de vários setores, em uma tentativa de levantar o povo "comum" ou "leigo" contra esse grupo.

\section{DISCURSO 3:}

"Nesse tema específico (das mulheres transgêneras e transexuais competirem junto com as mulheres cis nos esportes), eu estou com as mulheres e concordo com você (falando para a ex-atleta de vôlei Ana Paula Henkel). Eu acompanho esse debate [...].

Nós temos uma diferença biológica, não importa o estado em que ela se sente, como eles falam, se se sentem mulher agora, mas biologicamente, eles são superiores às mulheres. Gente, ó, não existe essa coisa de igualdade entre o homem e a mulher quando a gente vai para o campo da Biologia.

O homem é forte. Nós, mulheres, não vamos conseguir por muito tempo carregar um saco de cimento nas costas, mas eles não conseguem ver as coisas como a gente vê." Damares Alves, 17/01/2020, no programa "Pra cima deles", da Jovem Pan News ${ }^{35}$

O contexto da frase emitida por Damares vem de uma pergunta da jogadora de vôlei e ex-atleta Ana Paula Henkel sobre a possível participação do Estado na garantia do direito das mulheres cis para não serem excluídas do esporte em função das desigualdades biológicas em relação às trans. Todo o contexto já parte de uma narrativa que tem lado: o das atletas mulheres cis, pois a pergunta veio de uma ex-atleta mulher cis. Em resposta, Damares inicia sua fala, alegando estar "do lado das mulheres". E a que mulheres Damares estaria se referindo? Não seriam todas as mulheres, as cis e as trans? Estar do lado das mulheres, nesse caso, é não reconhecer discursivamente o lugar identitário de mulher das mulheres trans. O discurso já se coloca de início, portanto com o estabelecimento de uma exclusão e uma invisibilização das mulheres trans. Tal exclusão - mais que isso, violência de gênero - se mantém, na medida em que a ministra usa o pronome "eles" para se referir a elas em alguns momentos.

Em determinado ponto, o discurso estabelece uma comparação que revela uma forte raiz do pensamento dicotômico disseminado popularmente sobre gênero: os homens são fortes e as mulheres "veem" as coisas, sugerindo uma aura de intuição, sensibilidade e mistério que cerca o universo feminino essencialmente.

\footnotetext{
35 Disponível em: < https://jovempan.com.br/videos/programas/pra-cima-deles/pracimadeles-entrevista-
} com-a-ministra-damares-alves-17-01-2020.html>. Acesso em: fev. 2020. 
Os estudos de gênero chamam atenção para a produção e o reforço discursivo e normativo de dicotomias, nas quais a pluralidade e as nuanças de subjetividade se perdem. ${ }^{36}$ Tais autoras apontam que o estabelecimento de fronteiras linguísticas e conceituais sustentam as fronteiras de relações no mundo. Categorias dicotômicas, como homem/mulher, cis/trans, e conceitos essencialistas como "homem é isto, mulher é aquilo", eliminam as possibilidades e os arranjos identitários fluidos, dinâmicos e móveis, promovendo violências, exclusões e invisibilidades. Ademais, a fronteira revitaliza desigualdades, na medida em que socialmente alguns atributos são mais valorizados que outros, como a racionalidade em detrimento das emoções ou subjetividade. Nesse sentido, ao identificar as mulheres com a "visão" de algo que não se define, essa categoria é lançada a um lugar social de menor prestígio que o atribuído aos homens.

Apesar dessa atitude inconsciente da narrativa de diminuir as mulheres por meio da repetição de jargões que socialmente as desvalorizam, a narrativa traz seis vezes a palavra: "mulher(es)". O discurso está claramente buscando estabelecer uma aliança com esse grande grupo das mulheres, possivelmente em uma busca de resgatar o lugar de Damares entre esse universo de pessoas, que, em parte tende ao feminismo, com o qual Damares rivaliza. ${ }^{37}$

Finalmente, cabe indicar que esse discurso reforça a perspectiva da biologização, que tem sido utilizada no debate de gênero como justificativa para os desígnios de Deus para os corpos. Ao trazer a ênfase do debate para a biologia, os aspectos sociais de construção identitária tornam-se desvalorizados no discurso de Damares e a perspectiva de teocratização aparece. Para Damares, Deus fez homem e mulher, ambos cisgêneros - como se costuma propagar na ideologia de gênesis, que comunga com o dispositivo da cis-heteronorma. Qualquer alteração do corpo biológico seria um desvio no projeto divino. ${ }^{38}$ Judith Butler ${ }^{39}$ lembra que os corpos também são construídos na cultura (fazemos tatuagens, pintamos cabelo, nos maquiamos, usamos próteses) e que a dicotomia entre a natureza e a cultura é artificial.

\section{DISCURSO 4:}

“Atenção, atenção! É uma nova era no Brasil. Menino veste azul e menina, rosa.” Damares Alves, 02 de janeiro de $2019^{40}$

${ }^{36}$ BUTLER, Judith. Corpos que pesam: sobre os limites discursivos do sexo. In: LOURO, Guacira Lopes (Org.). O corpo educado. Belo Horizonte: Autêntica, 2001. p. 151-172. LOURO, Guacira Lopes. Gênero, sexualidade e educação. São Paulo: Vozes, 1997. BUTLER, Judith. Problemas de gênero: feminismo e subversão da identidade. Rio de Janeiro: Civilização Brasileira, 2003. MAFFÍA, 2008.

37 Disponível em: <https://www.youtube.com/watch?v=-_yWSMQEkY8>. Acesso em: fev. 2020.

38 ROSADO-NUNES, Maria José Fontelas. Gênero e religião. Rev. Estud. Fem. [conectados], v. 13, n. 2, p. 363-365, 2005.

39 BUTLER, 2001.

40 Trata-se de vídeo gravado no dia 02 de janeiro de 2019, após a cerimônia de posse. Disponível em: https:// www.jb.com.br/pais/2019/01/969894--nova-era-no-brasil--menino-veste-azul-e-menina-veste-rosa---dizdamares-em-video.html. Acesso em: jan. 2020. 
Esse discurso foi produzido no contexto da posse de Jair Bolsonaro em 02 de janeiro de 2019. No fervilhar das celebrações após o evento oficial, Damares é vista em meio às pessoas aliadas ao presidente em um clima festivo. $\mathrm{O}$ discurso, portanto, traz uma carga emocional evidente e saiu como um "grito de guerra" de torcidas.

A estratégia principal do discurso demonstra ser, ao mesmo tempo, cooptar aliados e aliadas e oferecer um recado a quem não atua ou não pensa na mesma linha ideológica que o governo: "agora é a vez do time que ganhou, a nova (velha) era (de gênero), na qual nossos valores prevalecerão". Novamente, vemos a prática de reforçar o vigor das fronteiras de pensamento, revitalizando dicotomias e binarismos. Lembremos que, conforme já observado em outros pontos de nosso texto, as fronteiras cognitivas promovem exclusões e apagamentos, já que algumas pessoas ficam do lado de dentro e outras são posicionadas fora da fronteira. Boaventura de Sousa Santos $^{41}$ chama esse mecanismo de pensamento abissal, que estabelece um abismo cognitivo entre as partes. Nesse sentido, o discurso está sendo dirigido principalmente a adversários e adversárias ideológicas do governo. Damares aparece empoderada no discurso, é como se naquele momento, em meio a seus aliados e suas aliadas, sua força estivesse exaltada e um mundo no qual os valores de seu grupo prevalecem.

A retórica utilizada é, primeiro, de chamamento para algo grandioso, que será um divisor de águas, uma (suposta) nova era. Em seguida, são utilizadas as metáforas: menino $=$ azul, menina $=$ rosa. A perspectiva de teocratização, apoiada na ideologia de gênesis, está bastante evidente nesse discurso. Os valores cristãos ligados à dicotomia entre o masculino e o feminino são evocados em um contexto de celebração. Está encoberta no discurso toda uma exclusão das identidades de gênero que não se encaixam na estética tradicional. $\mathrm{O}$ azul e o rosa são expressões da divisão binária e excludente que não permite espaço para qualquer arranjo identitário que escape a esses valores. A referência às cores tradicionais associadas aos universos masculino e feminino também se torna um mecanismo de exclusão ao grupo LGBT, que é conhecido pelas cores do arco-íris. "Já demos o anúncio, as outras cores do arco-íris não são bem-vindas, só azul e rosa". Tal conclusão, embora não esteja dita desse modo, pode ser depreendida do discurso, já que o mesmo estabelece metáforas bastante claras e binárias. Notemos que as dicotomias apresentadas caminham para o fortalecimento da visão de mundo cristã tradicional em detrimento da pluralidade presente no debate público.

\section{DISCURSO 5:}

"O Estado é laico, mas essa ministra é terrivelmente cristã." Damares Alves, 02 de janeiro de $2019^{42}$

Esse discurso foi pronunciado pouco depois da posse de Jair Bolsonaro pela ministra Damares Alves. Trata-se de uma narrativa de apresentação. "Vejam, essa mi-

${ }^{41}$ SANTOS, 2007.

42 Disponível em: < https://g1.globo.com/politica/noticia/2019/01/02/estado-e-laico-mas-esta-ministrae-terrivelmente-crista-diz-damares-ao-assumir-direitos-humanos.ghtml?utm_source=facebook\&utm medium=social\&utm_campaign=g1\&utm_content=post $>$. Acesso em: 02 jan. 2019. 
nistra é assim". O único verbo do discurso: "é" se repete duas vezes. Lembremos que, conforme anteriormente citado, para Foucault ${ }^{43}$, as repetições estão a serviço da consolidação da legitmidade do discurso. O verbo está no presente e evoca a permanência das coisas. Ser é normalmente colocado em oposição a estar, indicando uma situação mais sólida, que dificilmente se altera. O Estado é laico. A ministra é terrivelmente cristã. Fatos que são apresentados no discurso como opostos. ${ }^{44}$

Novamente, verificamos o resgate de uma fronteira: laicidade $\mathrm{X}$ religião, mesmo que conceitualmente e de maneira prática, tais princípios não sejam antagônicos. ${ }^{45}$ Conforme pudemos observar em nossas análises, trazer à tona as dicotomias é marca das práticas discursivas da ministra Damares Alves, mas também - como veremos - de outros e outras representantes do governo como o ministro Abraham Weintraub. Em princípio, a laicidade de Estado deve garantir a pluralidade religiosa e manter uma postura de mediação entre os grupos religiosos. No entanto, ao anunciar a dicotomia entre laicidade de Estado e cristianismo desse modo, Damares estabelece uma aliança com a comunidade cristã, de modo a legitimar suas práticas no governo a partir de então.

A palavra "terrivelmente" traz ênfase à identidade cristã associada à ministra. Não se trata de uma prática ou crença cristã qualquer, mas sim de uma "terrível", que pode ser lida como forte, enfática, entusiástica, mas também como ameaçadora, pesada, malvada. Para quem não é cristão, o discurso pode acuar. A evidente tentativa de teocratização do Estado nesse discurso leva-nos à compreensão de uma estratégia discursiva que evoca o desejo de lutar pelos valores cristãos diante de um Estado laico.

\section{DISCURSO 6:}

"Universidades que, em vez de procurar melhorar o desempenho acadêmico, estiverem fazendo balbúrdia, terão verbas reduzidas. [...]

A universidade deve estar com sobra de dinheiro para fazer bagunça e evento ridículo $[\ldots]$

Sem-terra dentro do campus, gente pelada dentro do campus." Abraham Weintraub, abril de $2019^{46}$

Esse discurso foi enunciado logo após a nomeação de Abraham Weintraub para o Ministério da Educação, em um contexto de anúncio de cortes na educação,

${ }^{43}$ FOUCAULT, 2016.

${ }^{44}$ Vale lembrar que Alves já havia declarado ser uma "advogada terrivelmente cristã”, expressão que utilizou para apoiar a psicóloga evangélica Marisa Lobo, defendida por ela da acusação de promover a "cura, restauração e libertação" de pessoas não heterossexuais e não cisgêneras (MACEDO, Cleber M. Ribeiro de. Pentecostalismo, performance e o acionamento de pânicos morais: o caso da pastora Damares. ANAIS do VII Seminário dos Alunos do Programa de Pós-Graduação em Antropologia Social do Museu Nacional. p. 134-147, 2017).

$45 \mathrm{O}$ tema da laicidade é complexo e não será foco neste texto. Para um aprofundamento, recomendamos o texto de CATROGA, Fernando. Entre deuses e césares: secularização, laicidade e religião civil. Coimbra: Almedina, 2006.

${ }^{46}$ Disponível em: <https://veja.abril.com.br/brasil/universidades-com-balburdia-terao-verbas-reduzidasdiz-weintraub/>. Acesso em: jan. 2020. 
conforme já apontamos em itens anteriores. Três universidades nesse momento foram indicadas como sendo alvo desses cortes por "balbúrdia": a UFF, a UNB e a UFBA.

O tom do discurso é de recado ou ameaça e trabalha com um contexto cognitivo de condicionante infantilizado: "Universidades, se fizerem balbúrdia, já sabem: cortes. Se vocês se comportarem dentro das nossas normas, receberão mesada". Tal ameaça torna o discurso de Weintraub uma amálgama entre público e privado, uma vez que uma gestão pública não contingencia verbas de acordo com o cumprimento ideológico das expectativas de quem atua na gestão. Esse é um exemplo de uma gestão com olhar privatizado para o campo educacional. Percebe-se que o discurso de Weintraub colide com alguns valores que são características de universidades públicas, como a pluralidade de pensamentos e a autonomia universitária, uma vez que o ministro cobra um alinhamento atitudinal das universidades à filosofia do governo, $\mathrm{o}$ que seria característico de uma gestão privada.

A palavra "balbúrdia" - que foi alvo de muita repercussão nas redes sociais - foi apresentada como um recurso retórico de impacto e é colocada como oposta à ideia de “desempenho acadêmico". Nesse sentido, balbúrdia poderia representar baixo desempenho. No entanto - e aqui utilizamos dados externos ao discurso para apoiar nossa análise -, as três universidades acusadas pelo ministro na época de sua fala de realizarem "balbúrdia" (UFF, UFBA e UNB), ao contrário do critério indicado pelo ministro, subiram em rankings universitários internacionais. ${ }^{47}$ Nesse sentido, a palavra "balbúrdia" evoca algo diferente de baixo desempenho acadêmico. Cognitivamente é uma palavra forte, que evoca um conjunto amplo de possibilidades semânticas, deixando aberto para o público em geral encaixar suas representações. A ameaça, nesse sentido, perde objetividade e adentra um campo subjetivo. "Como será que o ministro quer que a gente se comporte?"

Conforme se observa na segunda parte da narrativa, o desempenho acadêmico de fato não está ligado ao motivo dos cortes. Já que "balbúrdia" foi diretamente associada a comportamento de "bagunça", "gente pelada", "sem-terra"... Verificamos no discurso que o grupo dos "sem terra" é associado com bagunça e ridículo, de maneira que podemos identificar a visão do ministro da Educação acerca do Movimento dos Trabalhadores Sem Terra (MTST). Weintraub, ao articular educação com um movimento social, o faz de maneira a promover discursivamente uma aparente contradição entre esses campos, alijando o campo da educação de abordar um fenômeno social de magnitude no país.

\section{DISCURSO 7:}

"Eu nunca roubei. Não sou do PT. Pago do meu salário. Trabalhei a minha vida inteira com carteira de trabalho. Nunca recebi bolsa. 27,5\% de imposto. [...] Eu não tenho passagem na polícia que nem os petistas."

Abraham Weintraub, setembro de 2019

47 A reportagem disponível em: $<$ https://www.nsctotal.com.br/noticias/mec-cortara-verba-de-universidadespor-balburdia-diz-ministro $>$ (acesso em: fev. 2020) mostra que as três universidades subiram de desempenho nos últimos anos, levando em conta rankings como o da britânica Times Higher Education. 
Esse discurso foi enunciado em meio a uma discussão ocorrida em Alter do Chão, Pará, em setembro de 2019, entre Weintraub e um grupo de índios nativos. A cena ocorreu em uma área aberta de alimentação. Weintraub jantava com sua família, mulher e três filhos/as, quando um grupo de moradores e moradoras se manifestou por meio de um cartaz. Weintraub reagiu de maneira contundente. Iniciou-se uma discussão entre o ministro e um índio, ambos disputando microfone. Portanto, ao analisarmos esse discurso, vamos considerar o forte tom emocional que está ligado ao contexto dessa narrativa.

Já de partida vemos que se trata de um discurso de justificação e defesa que se inicia com uma referência à violência (roubo) e termina falando de outra violência (passagem na polícia). Em ambas as pontas do discurso o Partido dos Trabalhadores é citado em seguida à imagem violenta, sendo associado a roubo e passagem na polícia.

Há uma óbvia dicotomia discursiva: “eu, que trabalhei a vida inteira e nunca roubei" versus "vocês, petistas, com passagem na polícia". A clara aliança do discurso é com antipetistas. Novamente vemos um representante do governo Bolsonaro reforçar dicotomias em suas práticas discursivas, alimentando o pensamento polarizado.

A perspectiva de privatização aparece no momento em que ele aborda o trabalho com carteira assinada como um mérito, um louvor, em contraposição a ganhar bolsas, uma política associada em larga escala à área pública (embora não seja restrito à mesma). Vejamos que no discurso, enquanto Weintraub elenca as características que ele parece considerar reveladoras de sua perfeita atitude como cidadão trabalhador, ele cita o fato de nunca ter recebido bolsa. Como revela esse trecho, o discurso considera bolsa como um recurso que se opõe a um modelo de trabalho exemplar. Podemos afirmar, desde esse mecanismo, que Weintraub vê de maneira desvalorizada as bolsas de estudo. Considerando que parte fundamental da atuação de sua pasta, o Ministério da Educação, é administrar os recursos destinados à pesquisa, entre eles as bolsas, verifica-se uma alta incongruência entre o declarado no discurso 8 e seu papel como ministro.

\section{DISCURSO 8:}

"Ou é XY no DNA e se for fêmea XX. Mas se te disserem, ah, mas eu não tenho 'pipi'. Tudo bem, você pode ser um XY macho que nasceu sem 'pipi'. Agora, se você tem atração por outro sexo, vou tratar a pessoa com todo o respeito. A Roberta

Close, por exemplo, eu trataria como senhora, mas o DNA dela é de macho.”

Abraham Weintraub, outubro de 2019

Nesse discurso, proferido durante a $5^{\mathrm{a}}$ Conferência da Frente Parlamentar Evangélica do Congresso Nacional, realizada na Faculdade Boas Novas de Manaus, cujo tema foi "O Novo Brasil na Perspectiva Cristã", Weintraub demonstra sua pouca habilidade para tratar de assuntos relacionados a gênero e sexualidade.

Primeiro, o discurso propõe que gênero se enfeixa somente em "macho" (definido cromossomicamente como XY) e "fêmea" (compreendida cromossomicamente como XX). Conforme já observamos em itens anteriores, essa é uma estratégia discursiva fortemente utilizada no contexto leigo relativo ao tema de gênero e tal estratégia 
traz, como observa Bhabha ${ }^{48}$, um apagamento das diferenças, reduzindo-as a somente duas possibilidades. Weintraub demonstra desconhecer todo um amplo espectro de pessoas intersexos que não possuem tais conformações cromossômicas. Aliás, a fala do ministro foi complementada pela assertiva: "Na biologia é macho ou fêmea, não existe LGBTQI", que de modo insensível às diversidades de gênero e sexual invisibiliza e aniquila as subjetividades de todas as pessoas enfeixadas pelas siglas L (lésbicas), G (gays), B (bissexuais), T (transgêneras), Q (queer) e I (intersexo).

Além disso, gênero não se encontra entre as pernas e no DNA, mas sim na mente das pessoas. Há pessoas com cromossomos XY (de "macho" como observa o ministro), mas que se sentem (portanto, são) mulheres - como é o caso de muitas mulheres transexuais, o que é, de alguma forma, negligenciado por Weintraub. Também confunde identidade de gênero (a transexualidade da modelo Roberta Close) com sexualidade ("se você tem atração por outro sexo") e com sexo biológico ("ou é XY no DNA e se for fêmea XX").

Weintraub demonstra sua perspectiva biologizante relacionada a gênero e sexualidade, entendendo "XY para macho e XX para fêmea". A perspectiva biologizante de gênero é uma percepção usual em discursos cristãos tradicionalistas, conforme aponta Maria José Fontelas Rosado-Nunes:

O primeiro objetivo dos estudos de gênero é desconstruir o preconceito de que a biologia determina o feminino, enquanto que a cultura ou a dimensão humana é uma criação masculina. Essas linhas diretivas do pensamento feminista têm nas religiões suas principais antagonistas, uma vez que estas definem "a natureza humana" como resultado de uma determinação divina intocável. As religiões têm, explícita ou implicitamente, em seu bojo teológico, em sua prática institucional e histórica, uma específica visão antropológica que estabelece e delimita os papéis masculinos e femininos. O fundamento dessa visão encontra-se em uma ordem não humana, não histórica, e, portanto, imutável e indiscutível, por tomar a forma de dogmas. Expressões das sociedades nas quais nasceram, as religiões espelham sua ordem de valores, que reproduzem em seu discurso, sob o manto da revelação divina ${ }^{49}$.

Por tratar dentro dessa chave de entendimento durante um evento evangélico, empunhando a Bíblia nas mãos (veja foto abaixo), fica claro que seu discurso enfeixa-se no dispositivo da cis-heteronorma que comunga com a ideologia de gênesis: na perspectiva de Weintraub, há um único gênero e orientação sexual desejáveis e supostamente abençoados pelo Criador, a cisgeneridade e a heterossexualidade. Aqui vemos a perspectiva de teocratização de maneira explícita, interferindo em falas públicas do ministro.

Na mesma palestra, Weintraub também teceu críticas à esquerda brasileira, que teria como pretenso intuito "destruir a família brasileira", inclusive a partir do livro "O Capital" de Karl Marx, mencionado por ele como um livro profano em que estaria

\footnotetext{
${ }^{48}$ BHABHA, 1998.

${ }^{49}$ ROSADO-NUNES, 2005, p. 363.
} 
escrito que para se mudar a sociedade os valores familiares deveriam ser quebrados. Segundo o ministro, "por isto que eles querem quebrar nossas referências familiares. Por isso que eles atacam a Bíblia e nos atacam quando falamos sobre religião", complementando que "é preciso saber onde atacar para não ser derrotado". Como visto, Weintraub opera em uma lógica beligerante fundada no pânico moral alicerçado pela suposta "destruição da família" a partir de ideologias como o comunismo e o gênero.

Imagem: Weintraub fala sobre "macho"e "fêmea" durante a 5a . Conferência da Frente Parlamentar Evangélica do Congresso Nacional

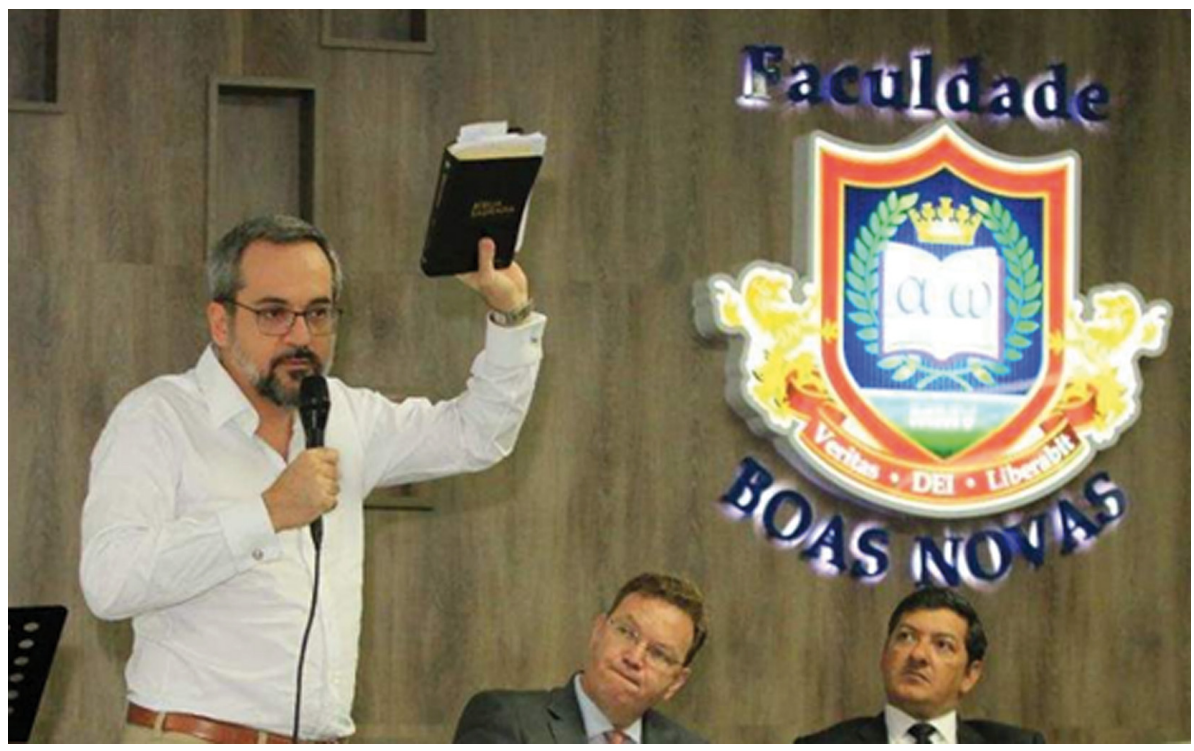

Fonte: $<$ https://www.acritica.com/channels/manaus/news/na-biologia-e-macho-ou-femea-naoexiste-lgbtqi-diz-ministro-da-educacao-em-manaus $>$

\section{Considerações finais}

Observamos na análise das práticas discursivas desses três representantes do governo - cujas políticas, falas e ações interferem na educação do país - que as dicotomias e os pensamentos de fronteira e trincheira são evocados constantemente pelo grupo. Isso indica que o campo da educação tem sido afetado por essa postura beligerante, que acaba estabelecendo alianças apenas com pessoas e entidades que estejam alinhadas com a ideologia do governo, excluindo grupos que estejam posicionados em outros espectros ideológicos. Nesse contexto, eliminam-se as múltiplas possibilidades do espectro, reforçando os polos "nós" e "eles".

Além desse mecanismo estratégico, os discursos apontam para as perspectivas de privatização e teocratização na medida em que favorecem valores de um grupo específico em detrimento das diretrizes mais amplas do debate democrático que apontam para a pluralidade, em uma amálgama de propostas que envolvem o reforço ao 
núcleo familiar, religioso e de mercado. Levantamos ser possível pensar, ainda, que os discursos fundamentados em perspectivas relacionadas ao dispositivo da cis-heteronorma - que comungam estritamente com a ideologia de gênesis - atuam, de alguma forma, não só na teocratização e privatização de um determinado modelo de família, como na teocratização e privatização da sexualidade e do gênero.

Portanto compreeendemos a partir dos dados observados que a educação no governo Bolsonaro está submetida a uma lógica que apequena as possibilidades presentes em uma democracia, o que prejudica a perspectiva de educação em diversidades e direitos humanos, na qual a exposição e conscientização para a pluralidade é condição fundamental.

\section{Referências}

BENEVIDES, Maria Victoria. Direitos humanos: desafios para o século XXI. In: SILVEIRA, Rosa Maria Godoy et al. Educação em Direitos Humanos: Fundamentos teórico-metodológicos. João Pessoa: Editora Universitária, 2007. p. 335-350.

BHABHA, Homi K. O Local da Cultura. Belo Horizonte: UFMG, 1998.

BUTLER, Judith. Corpos que pesam: sobre os limites discursivos do sexo. In: LOURO, Guacira Lopes (Org.). O corpo educado. Belo Horizonte: Autêntica, 2001. p. 151-172.

. Problemas de gênero: feminismo e subversão da identidade. Rio de Janeiro: Civilização Brasileira, 2003.

CANCLINI, Néstor Garcia. Culturas Híbridas. São Paulo: EDUSP, 1998.

CATROGA, Fernando. Entre deuses e césares: secularização, laicidade e religião civil. Coimbra: Almedina, 2006.

FOUCAULT, Michel. A arqueologia do saber. 8. ed. Rio de Janeiro: Forense, 2016. . A ordem do discurso. São Paulo: Loyola, 1996.

. Estratégia, poder-saber. Rio de Janeiro: Forense Universitária, 2012. (Coleção Ditos

e Escritos, v. 4).

FRANCO, Clarissa De. "A Educação oprimida: perspectivas de privatização e teocratização ameaçam o setor". Folha online. Opinião. Tendências/Debates. 05/02/2020. Disponível em: $<$ https:// www1.folha.uol.com.br/opiniao/2020/02/a-educacao-oprimida.shtml >. Acesso em: fev. 2020. GARBAGNOLI, Sara; PREARO, Massimo. La croisade "anti-genre". Du Vatican aux manifs pour tous. Paris: Textuel, 2017. (Coll. Petiteencyclopédie critique, 128).

LEMOS, Carolina Teles. Religião e Patriarcado: elementos estruturantes das concepções e das relações de gênero. Caminhos, Goiânia, v. 11, n. 2, p. 201-217, jul./dez. 2013.

LIMA, Kátia. Plano Nacional de Educação 2014-2024: nova fase do privatismo e da certificação em larga escala. Universidade e Sociedade/ANDES-SN, fev. 2019.

LOURO, Guacira Lopes. Gênero e sexualidade: pedagogias contemporâneas. Pro-Posições, v. 19, n. 2 (56), maio/ago. 2008.

Gênero, sexualidade e educação. São Paulo: Vozes, 1997.

MACEDO, Cleber M. Ribeiro de. Pentecostalismo, performance e o acionamento de pânicos morais: o caso da pastora Damares. ANAIS do VII Seminário dos Alunos do Programa de Pós-Graduação em Antropologia Social do Museu Nacional. p. 134-147, 2017.

MAFFÍA, Diana. Contra las dicotomías: feminismo y epistemología crítica. Instituto Interdisciplinario de Estudios de Género, Universidad de Buenos Aires, 2008. 
MARANHÃO Fo , Eduardo Meinberg de Albuquerque. "A travesti morreu, mas carrego ela no caixão" e outras histórias vivas: conversão, transfobia religiosa e morte. Revista Brasileira de História das Religiões, v. 10, n. 9, p. 165-216, 2017.

MARANHÃO Fo , Eduardo Meinberg de Albuquerque; COELHO, Fernanda Marina Feitosa; DIAS, Tainah Biela. "Fake news acima de tudo, fake news acima de todos": Bolsonaro e o "kit gay", "ideologia de gênero" e fim da "família tradicional". Correlatio, v. 17, n. 2, p. 65-90, 2018. MARANHÃO, $\mathrm{F}^{\circ}$., Eduardo Meinberg de Albuquerque. "Matando uma leoa por dia": ideologia de gênero e de gênesis na "cura" de travestis. Correlatio, v. 17, n. 2, p. 107-148, 2018.

MARANHÃO, $\mathrm{F}^{\circ}$., Eduardo Meinberg de Albuquerque; FRANCO, Clarissa De. "Menino veste azul e menina, rosa" na Educação Domiciliar de Damares Alves: As ideologias de gênero e de gênesis da "ministra terrivelmente cristã" dos Direitos Humanos. Revista Brasileira de História das Religiões, ANPUH, ano XII, n. 34, 2019.

MARIANO, Ricardo. Laicidade à brasileira. Católicos, pentecostais e evangélicos em disputa na esfera pública. Revista Civitas, v. 11 , n. 2, p. 238-258, maio-agosto 2011.

ORLANDI, Eni. Educação em direitos humanos: um discurso. In: SILVEIRA, Rosa Maria Godoy et al. Educação em Direitos Humanos: Fundamentos teórico-metodológicos. João Pessoa: Editora Universitária, 2007. p. 295-311.

REZERAI, Danielle do Nascimento; D’ALEXANDRE, Raquel Gomes. Os desafios da educação: Intolerância e inconstitucionalidade do Manifesto à nação (FPE) do programa de governo de Jair Bolsonaro. Revista Interinstitucional Artes de Educar, Rio de Janeiro, v. 5, n. 2, p. 293-312, maio/ago. 2019.

ROSADO-NUNES, Maria José Fontelas. A “ideologia de gênero" na discussão do PNE: a intervenção da hierarquia católica. Horizonte, Belo Horizonte, v. 13, n. 39, p. 1.237-1.260, 2015. Gênero e religião. Rev. Estud. Fem. [conectados], v. 13, n. 2, p. 363-365, 2005.

SANTOS, Boaventura de Sousa. Para além do Pensamento Abissal: das linhas globais a uma ecologia de saberes. Revista Crítica de Ciências Sociais, v. 78, n. 1, p. 346, 2007.

SANTOS, Pablo Silva Machado Bispo dos. Guia prático da política educacional no Brasil: Ações, planos, impactos. 2. ed. Cengage Learning, 2012.

SILVEIRA, Rosa Maria Godoy et al. Educação em Direitos Humanos: Fundamentos teórico-metodológicos. João Pessoa: Editora Universitária, 2007.

\section{Internet}

https://www.youtube.com/watch?v=-_yWSMQEkY8. Acesso em: fev. 2020.

https://brasil.elpais.com/brasil/2019/09/08/politica/1567961873_908783.html. Acesso em: jan. 2020. https://brasil.elpais.com/brasil/2020-02-08/censura-de-livros-expoe-laboratorio-doconservadorismo-em-rondonia.html. Acesso em: fev. 2020.

https://g1.globo.com/educacao/noticia/2019/05/15/entenda-o-corte-de-verba-das-universidadesfederais-e-saiba-como-sao-os-orcamentos-das-10-maiores.ghtml. Acesso em: jan. 2020.

https://g1.globo.com/politica/blog/andreia-sadi/post/2019/01/25/damares-educacao-domiciliarpermite-a-pais-ensinar-mais-conteudo-e-gerenciar-aprendizado.ghtml. Acesso em: fev. 2020.

www.escolasempartido.org www.programaescolasempartido.org. Acesso em: nov. 2018.

https://www1.folha.uol.com.br/poder/2019/01/leia-a-integra-do-discurso-de-bolsonaro-nacerimonia-de-posse-no-congresso.shtml. Acesso em: fev. 2020.

https://g1.globo.com/jornal-nacional/noticia/2020/01/28/novo-presidente-da-capes-gerapolemica-ao-defender-criacionismo.ghtml. Acesso em: 26 jan. 2020.

https://www.jb.com.br/pais/2019/01/969894--nova-era-no-brasil--menino-veste-azul-e-meninaveste-rosa---diz-damares-em-video.html. Acesso em: jan. 2020. 
Damares Alves no programa da Joven Pan News "Pra cima deles". Disponível em: https:// jovempan.com.br/videos/programas/pra-cima-deles/pracimadeles-entrevista-com-a-ministradamares-alves-17-01-2020.html. Acesso em: fev. 2020.

G1. 02 jan. 2019. Disponível em: https://g1.globo.com/politica/noticia/2019/01/02/estadoe-laico-mas-esta-ministra-e-terrivelmente-crista-diz-damares-ao-assumir-direitos-humanos. ghtml?utm_source=facebook\&utm_medium $=$ social\&utm_campaign=g1\&utm_content=post. Acesso em: 02 jan. 2019.

https://veja.abril.com.br/brasil/universidades-com-balburdia-terao-verbas-reduzidas-dizweintraub/. Acesso em: jan. 2020.

https://www.facebook.com/watch/?v=2904831652882454. Acesso em: fev. 2020.

Em vídeo, Damares diz que "nova era" começou: "meninos vestem azul e meninas vestem rosa". G1 (03 jan. 2019). Disponível em: https://g1.globo.com/politica/noticia/2019/01/03/ em-video-damares-alves-diz-que-nova-era-comecou-no-brasil-meninos-vestem-azul-e-meninasvestem-rosa.ghtml?utm_source $=$ facebook\&utm_medium $=$ social\&utm_campaign=g $1 \& u t m$ content=post. Acesso em: 03 jan. 2019.

"Estado é laico, mas esta ministra é terrivelmente cristã", diz Damares ao assumir Direitos Humanos. G1 (02 jan. 2019). Disponível em: https:/g1.globo.com/politica/noticia/2019/01/02/estadoe-laico-mas-esta-ministra-e-terrivelmente-crista-diz-damares-ao-assumir-direitos-humanos. ghtml?utm_source=facebook\&utm_medium $=$ social\&utm_campaign=g $1 \& u t m \_c o n t e n t=$ post. Acesso em: 02 jan. 2019.

https:/educacao.uol.com.br/noticias/agencia-estado/2019/04/30/mec-cortara-verba-deuniversidade-por-balburdia-e-ja-mira-unb-uff-e-ufba.htm. Acesso em: jan. 2020.

https://www.acritica.com/channels/manaus/news/na-biologia-e-macho-ou-femea-nao-existelgbtqi-diz-ministro-da-educacao-em-manaus. Acesso em: jan. 2020.

https://www.nsctotal.com.br/noticias/mec-cortara-verba-de-universidades-por-balburdia-dizministro. Acesso em: fev. 2020. 